報告

\title{
アメリカ人間工学会第18回年会に出席しで
}

\author{
大 川 雅 司**
}

\begin{abstract}
わが国にも增して見事な紅葉で郊外を埋めつくしていた Alabama 州 Huntvill 市で, 10 月 15 日 から 17 日の 3 日間, Human Factors Society (HFS) の第 18 回年次大会が開催された。筆者は会 長の Prof. Stanley Johns の招きに応して参加したので内容を簡単に報告する.
\end{abstract}

Huntvill 市はかつて一度だけ訪れた 経験があるけれ ど, ここは米航空宇宙局（NASA）の宇宙開発センター の一つがあり,これに関連した宇宙産業やエレクトロニ クス産業のオフイスが点在している静かな小都市で, Sheraton Inn という開催場所のせいもあって，前回の Washington, D. C. の場合にも増して落着いた大会であ った.

今回のメーン・テーマは “benefits for mankind” で あり，32のセッション構成で行なわれたが，ここで幾つ かの有意義な発表例を紹介し，それぞれのセッションで 発表されたテーマと演者を列挙した.

\section{Public transportation}

"Human factors research in urban transportation", H. McIlraine Parsons は PRT (personal rapid transit) system, demand-responsive system(たとえばデマンド・ バス), 鉄道および旅行のモード選択など公共交通システ ムないし都市交通システムについて展望している. 米国 でのこの領域は極めて盛んで, 交通の課題は単体的アプ ローチではなく，システム・アプローチが殆んどを占め ている. 米国運輸省 (DOT) の下部組織として Boston に Transportation System Center (TSC) があり, 直 轄研究のほか, 政府機関や大学, 研究開発会社, メーカ 一などの研究調整を行なっており, この中で, マン・マ シン・シンテム研究がもろもろのプロジェクトを持って いることはわが国ではあまり知られていない.

"Psychological design factors in urban public transportation vehicles", S. Keith Adams \& Laverne L. Hoag.

\footnotetext{
* 昭和 49 年11月 12 日受付

** 日本電気株式会技術部
}

"Human factors involved in current public attitudes toward public transit concepts", John N. Fox.

"Bus modification to improve safety, comfort and human reliability", Catherine Stewart.

\section{Man computer interface}

"PLANS : Human factors in the design of a computer programming language”, H. Rudy Ramsey では, Programming Language for Allocation and Network Scheduling (PLANS) を紹介している。 これは資源問 題やスケジューリング課題用で, 階層データ構造を有 し，言語機能設計プロセスとインプルメンテーション・ プロセスのインタフェースは明確な機能定義づけが可能 であるとしている.このようなコンピュータ・プログラ ム言語は毎年, 幾つかのものが発表されている.

"Information display speed $\&$ noise in the design of computer terminals", Robert Beron \& William J. Duffy.

"Computer compatibility with decision style : Eddise in a bit stream", Michael H. Sturb \& Robert A, Levit.

\section{Aviation research}

"Development of a training model for Naval flight students”, Richard H. Shannon は, 部分-全体飛行訓 練モデルを開発している.これは操縦の詳細記述法の開 発, クリテイカル・エラーの分離, インフライト/シミ ュレータ・シナリオの開発を含み, 手法的に他システム にも適用が可能と思われる.

"Basic attention measures as predictors of success in flight training", Robert A. North \& Daniel Go. pher. 
"Pilotage error in area navigation : Effects of approach procedural complexity”, Richard S. Jensen.

"The transition of experienced pilots to a frequencyseparated aircraft attitude display : A flight experiment", Denis B. Berringer et al.

\section{Safety}

"A computer simulation model to analyze occupational safety and Health problems \& countermeasures", Alan E. Diehl はソシオ・テクニカル問題に適用してき たシステム・ダイナミックス・モデルの楧造上の特徴で ある要因相互関係やフィードバック関係など安全問題に 利用しようとする試みで着眼点が面白い.

"Percption, decision making \& skill as related to a boating operator's performance" C. Christian Stiehl \& James M. Miller.

"Risk-taking in skilled task performance", Jasper E. Shealy.

"A study of bicycle design as it affects safety of operation". Jerry L. Purswell et al.

"Identifing human factors causes from boating accident data", James M. Miller.

\section{Control/display design}

"On the importance of structure in processing multi-element visual displays”, Dov Zohar は, 多重 要素ディスプレイの空間構造を取り上げ, 実ワールドの ディスプレイは本質的構造を維持し, かつ, 人間検査者 の情報処理モードが直列的よりも階層的であることに着 目を要するという. また，表示構造処理における時間的 優先順位, 構造中心設計時の最小時間遅れなどディスプ レイ構造の実験的検討を報告している.

"Keyword visual display enhancement on computer printouts by overprinting", Thomas F. Higgginbotham.

"Effect of ambient illumination on legibility of displays of liquid-crystals \& light emitting diodes", Jerry Duncan \& Stephan Konz.

"A comparison between standard and reduced detail maps in a tactical operations system", Thomas M. Granda.

\section{Aerospace systems}

“Large space telescope and human factor", H. T. Fisher では, NASA が1980年に予定しているスペーシ
ヤルトル用の大型宇宙望遠鏡を中心とするヒューマン・ ファクターズ・プログラムを報告している. これは光学 技術実験システム検討, 奏寸ハードモップ利用およびル ープ中の人間シミューレーション, 船外保全概念, シス テム設計と装置設計などを含む.

“Control-display-stability angmentation system", Evan P. Rolek では, ヘリコプタはアビオニクスが久 けているために低視程もしくはゼロ視程では飛行ケイパ ビリティがない. 従って完全自動システムよりも, 手動 制御による計器飛行で性能を问上させかつ作業負荷を低 減させるj式を検討している.

"Some psychological contributions to defenses against hijackers", John T. Dailey \& Evan W. Pickrel.

"Skylab's astronaut maneuvering unit (Experiment M 509)-A comparison of six degree of freedom simulation \& on-orbit flight", A. M. Ray.

"Teleoperator spacecraft control station configuration development", Richard A. Spencer \& J. Robert Tewell.

“The ASSESS Program-documenting \& evaluating low cost techniques for conducting research in the flight environment", Leon B. Weaver.

"Evaluation of localized muscle fatigue using power spectral density analysis of the electromylogram", Earl V. LaFevers.

"Paths of movement of body members in aircraft cockpits", S. Deivanayagam et al.

\section{Defense systems}

“System performance test", Richard D. Kavanangh, はフィールドにおけるシステムの実性能の决定法, シス テム性能に関するヒューマン・エラー源の分離, ヒュー マン・エラー源の低減法の探索（システム構成要素の再 設計, システムに新構成要素を導入, 操作の新しい方法 もしくは手順の開発と試験, 新訓練手法の推奖など）に ついて述べている.

"Effects of time, rate of information presentation and physical threat stress on perceptual-motor performance", Jerry M. Owens et al.

"Navigation \& flight proficiency under nap of the earth conditions as a function of aviator training and experience", Michael L. Fineberg.

\section{Human Facotrs Methodology}

"A computer aided function allocation and evalua- 
tion system (CAFES), Charles W. Hutchins は, い わゆるクルー・システム設計を中心にしてシステム有効 度の解析と評価のために自動データ処理を用い, 以下の コンピュータ・モデルからなる. 1）機能配分モデル (FAM)ークルーの大きさと自動化レベルの决定, タス ク配分の最適化など，2）作業負荷アセスメント・モデ ル (WAM) 一機能配分の実現可能性とクルー手順, ク ルー・ステーション・コンフィギュレーションの評価と 最適化, 3） コンピュータ・エイデッド・クルー・ステ ーション設計 (CACSD)ーコンフィギュレーション・レ イアウトをコントロール／ディスプレイ要件, システム 制約条件, 設計基準から誘導, 4） クルー・ステーショ ン・ジォメトリ評価 (CGE)一詳細なクルー・ステー ション・コンフィギュレーションを人間オペレータとの 人体的コンパティビリティと, パフォーマンス・データ から誘導，5）人間オペレータ・シミュレータ（HOS） 一統合的マンーマシン・システムのシミュレーションに より各種の使命やシステム環境における人間パフォーマ ンス推定值を誘導. なお, CAFES はトレード・オフ解 析ルーチンも備えている.

"Computer-aided generation of performance measures for man-machine systems", Edward M. Connelly はオペレータ・パフォーマンスのメジャーを誘導するコ ンピュータ・エイデッド・システム (CAS) を構成して いる.このためにパフォーマンス測定プロセッサを用い るほか, 測定研究のインタラクティブ・マンーマシン・ システム・アプローチとして統合化される, 人間機能と コンピュータ・プロセッサの論理的区分を詳しく説明し ている.

"Human factors engineering test and evaluation technology”, Edward L. Holshouser.

"Incorporating knowledge that data will be missed in the design of human factors experiments", Gary D. Herrin.

"Design option decision tree : A method for schematic analysis of a design problem and integration of human factors data", William B. Askren \& Kenneth D. Korkan.

"Target detection assessment using an orthogonal mixedfactor central-composite design", Lawrence A. Scanlan \& Christine Clark.

"Electromyography in dynamic muscular loading", T. M. Khalil \& J. E. Otero.

"A theoretical and empiriçal comparison of two mixedfactor central-composite design”, Christine Cla- rk.

"Model development and the assessment of competing model”, Mark G. Pfeiffer \& Arthur I. Siegel.

"Baseline performance measurement for human performance evaluation", william A. Spindell \& Fredrick G. Knirk.

\section{Training and Education}

"A guide for developing performance-structure oriented computer administered instruction : theory and research", A. S. Blaiwes and J. W. Rigney は CAI の諸課題について検討し, 特に PSO, CAI-の利用 についてインストラクション戦略, CAI システムの要素

(内部処理, 生徒一課題インタフェース, 生徒データ, 適応制御者, インストラクショナル・シーケンス, フィ ードバック・ループ), また, PSO, CAI の仕様作成手 法, 実用例などを詳述している.

"Instructional system design for aircrew training", Steven C. Johnson et al.

"System approach to training (SAT) for the B-1 Aircrew", Robert C. Sugarman et al.

\section{Teleoperators and Human angmentation}

"A hierarchical concept for man-machine Communication”, J. S. Albus, et al. は米国家標準局 (NBS) のオートメーション技術プログラムに従って開発した. 大脳モデル連接制御者 (CMAC) の報告である.これは 特にマニピュレータ制御に用いるもので, 高レベル・タ スク向きコマンドで一連の運動アクチュエータ信号に分 解できるコンピュータ・ベースド制御システムである. 特徽は, マンーマシン・コミュニケーションを促進する ために階層構造を有する沉用の適応制御概念と, 記憶駆 動制御システムが組み込まれていることにある.

"Optical range \& range rate estimation for teleoperator systems", Nicholas L. Shields et al.

"A manipulator system designed for free flying teleoperator spacecraft”, J. R. Tewell et al.

"Man-machine interactive imaging and data processing using high speed digital mass storage", $H$. Alsberg \& R. Nathan.

\section{Extra vehicular activity}

“Skylab EVA system development”, Richard T. Heckman は米航空宇宙局 (NASA) によるアポロやジ エミニの船外活動 (EVA) の展望的報告で, 構想開発, マンノシステム・シミュレータ, 開発用シミュレーショ 
ンなどに触れている.

"Skylab extravehicular activity", David C. Schultz et al.

"The role of manned extravehicular activity in reducing the cost of space peayloads", Larry R. Alton \& J. W. Patrick.

"Review of extravehicular activity for the shuttle program", John H. Covington.

以上, 新しいトピックスの一部の紹介を試みた. この 他, 各セッションの研究発表をつぎのようである.

\section{Health care delivery}

"Tâsk analysis of anesthesia for coronary artery bypass surgery: Can computers help?”, Peter J. Kennedy et al.

"Biostereometrics: The spatial and spatio-temporal analysis of body form and function", Robert E. Herron.

"The value of chairside dental assistant", Tarek M. Khalil et al.

"Task analysis \& reinforcement strategies for the mentally disturbed : An interdisciplinary approach to behavioral engineering", Leonard Silverstein.

\section{Driver behavior}

"How engineering psychologists can improve night driving safety : Automobile head-lighting research", Rudolf G. Mortimer et al.

"The effects of ethyl alcohol on driving skill, visual perception, risk acceptance, choice reaction times and information processing rates", Helmut $T$.

Zwahlen.

"Relationship between predicted stress and measured attentional demand in a simulated driving task", L.

Bruce McDonard \& Newton C. Ellis.

"The effects of age and visual capability on performance with plane and convex mirrors", Ronald R. Mourant \& Ruth Dewald.

"The effect fo knowledge of lateral G performance on driving through curves', Malcolm L. Ritchie and John M. Howard.

"Prediction of drivers' location", Susanne M. Gatchell \& James M. Miller.

"An investigation of the effects of reinforced stimuli on driver brake reaction", Ralph W. Plummer et al.

"A methodology for child safety seat", Robert P. Meyer \& John I. Laverson.

"Evaluation of driver comprehension of word versus symbol highway signs", Ralph W. Plummer et al.

\section{Behavior and Attitudes in man-made envi- ronment}

"Space utilization and architectural planning in a drug rehabilitation center", Henry E. Bender et al.

"General solutions to nurses travel in linear and circular nursing units", Stanley Lippert.

"Human factors and environmental design in military food service facilities : A survey approach", Lawrence E. Symington \& Herbert L. Meiselman.

"Human factors analysis of modular furniture systems", Andrew D. LeCocq.

\section{Stress \& behavior}

"Effects of occupational exposure to inorganic lead on neuromuscular functioning", John D. Repko et al.

"Counteracting psychological fatigue effects by stimulus change", Corwin A. Bennet et al.

"Prediction of cardiac response to physical stress", Larry E. Long \& Laverne L. Hoag.

"A review of the effect of menstruation on accident involvement, size of visual field, and color percption”, Kathryne M. Lanfair and Leo A. Smith.

"Methods for measuring reduced work capacity as a function of continuing work : A critical review", Gerald F. Rabideau \& Barbara J. Maddux.

\section{Handtools}

"Design of handtools",Stephan Konz.

"Toward a theory of man-tool system design application to the consumer product area", John G. Kreifeldt \& Percy H. Hill.

"Human factors design of writing instruments for children : The effects of pen size variation", Henry S. R. Kao.

"Static \& dynamic characteristics of tooth brushing”, John G. Kreifeldt \& Percy H. Hill.

\section{Response to disaster (Symposium)}

"Weakness in disaster planning", E. L. Quarantelli. 
"Human response to disaster", Charles E. Fritz.

"A pictorial description of the xenia tornado", Glen

R. Gallaway.

\section{Employee motivation \& Job enlargement}

"The ten commandments for organizational effectiveness", Stuart O. Parsons.

"Designing 'good' jobs : Countermeasures and controls", Richard O. Peterson.

"The food service worker in the military dining facility : Job satisfication, training and human factors", Lawrence E. Symington.

"The vocational opinion index : Developed to measure attitudes toward work", Stephan D. Benson \& Marna C. Whittington.

\section{Human factors test \& evaluation}

"The accommodated proportion of a potential user population : Compilation and comparisons of methods for estimation", Alvah C. Bittner, Jr. and william F. Moroney.

"Comparing adjectival and non-adjectival rating scale responses against performance criteria", wade R. Helm.

"Human factors consideration for the U. S. Army test bed aircraft system", Andrew D. LeCocq.

"Techniques for reviewing military standards/specifications", william F. Moroney et al.

\section{Human factors in industry}

"Using psychological job heaviness assesssment technique to indentify high demand elements in production work", Richard L. Lucas.

"Force exertion during lifting with light loads", R. Perkins \& Stephan Konz.

"Strategies for improving visual inspection performance", Jerry L. Purswell \& Laverne L. Hoag.

"Human factors in industry-Getting the point across", Richard L. Lucas.

\section{Human performance research}

"Effect of environmental extemes on task performance time", Fredrick W. Trabold, Jr. \& Daniel B. Jones.

"The effects of verbal interference on psychomotor performance under dual task conditions", Wads R. Halm et al.

"The effects of whole-body exercise on choicereaction time performance", Alan B. Dechovitz et al.

"The measurement of attention capacity through concurrent task performance with individual difficulty levels and shifting priorities", Daniel Gopher \& Robert A. North.

"Interaction of the circadian rythm with the effects of condition continuous work and sleep II" Glynn

D. Coates et al.

"Evaluation of prior experience in skilled performance", Stanley Lippert.

"Models of response time to perpheral stimuli", D. S. Kochar \& T. M. Fraser.

"Manipulating the number and type of adaptive variables in training”. Daniel Gopher et al.

"Color research for visual displays" Richard E. Christ.

"Prediction of target detection thresholds on the basis of physiological considerations", Arthur Bernstein.

\section{Human Resources}

"Preview of the special issus of human factors on human resources as criteria for system design and organization planning", William B. Askren.

"Human effectiveness and evaluation", Gloria Lauer Grace.

\section{Communications systems}

"Dimensions of interpersonal communication", Myron Wish.

"Human factors engineering aspects of satellits communication systems", James W. Kuhr \& Leonald W. Tobias.

なお，大会中およびその後に接触した HFS のアクテ ィブ・メンバーによれば, 最近の“システム関係”の報告 は関連の他学会, たとえば IEEE, IFIP, IFAC, ASME などに流れやすい傾向にある. 従ってこの対策に苫慮し ている. 